\title{
Hantu Perempuan Jawa dalam Alaming Lelembut Sebagai Representasi Femme Fatale
}

\author{
Umi Halimah \\ Alumna Program Studi Magister Ilmu Susastra Universitas Diponegoro
}

\begin{abstract}
This study entitled "The Javanese Female Ghost in 'Alaming Lelembut' as a Representation of Femme Fatale"aims to show the feminist value in Javanese horror stories with female ghost as a villain and men as most of their victims. This study uses feminism as a main approach and femme fatale theory as the specific approach theory. This study shows that there are three kinds of of female ghost, they are female ghosts who experienced a miserable life before her death, sensual women and women whose background is not known. For the three kinds of women it can be revealed the causes of the female spirits to become evil spirits, the modes of female ghosts to ensnare and trap victims, the female ghost's harmful effects to men, and the solutions as the anti-climac in the story.
\end{abstract}

Key Words: ghost, woman, feminism, femme fatale, patriarchal.

\section{Pendahuluan: Panjebar Semangat dan Perkembangan Sastra Jawa}

Sastra majalah merupakan penyalur informasi dan sastra berbahasa Jawa masih produktif hingga saat ini. Novel berbahasa Jawa terbit silih berganti namun majalah menawarkan pengalaman yang lebih ringan, beragam, menghibur dan instan. Majalah Panjebar Semangat yang pertama kali terbit pada tahun 1933 di Surabaya adalah majalah berbahasa Jawa tertua dan masih terbit tiap minggu hingga sekarang meski pernah dilarang terbit oleh pihak penguasa antara tahun 1942 hingga 1949 (Rass, 1985: 19).

Karya sastra dalam bahasa Jawa pada awalnya memiliki aturan yang ketat mengenai tata tulis dan isi tulisan, seperti harus berbentuk tembang, dengan jumlah suku kata, jumlah baris, jumlah bait dan persajakan yang baku. Aturan yang tak kalah ketat juga diterapkan dalam hal isi dari karya sastra berbahasa Jawa. Kebanyakan berisi tentang ajaran-ajaran hidup, yang menunjukkan bahwa pada awalnya, yang paling dominan dari karya sastra Jawa adalah nilai didaktis dan pragmatisnya.

Bahasa Melayu yang karya sastranya memindahkan bahasa lisan ke dalam tulisan tentu jauh berbeda dengan karya sastra Jawa yang merupakan hasil dari tradisi sastra tulis yang telah berusia ratusan tahun yang sejak semula berasal dari kraton dan tentu tidak digunakan untuk kebutuhan praktis sebagai bahasa lisan (Damono, 1993:15). Tata aturan yang ketat yang berlaku pada karya sastra Jawa pada saat itu membuatnya menjadi bacaan untuk kalangan yang sangat terbatas.

Setelah Belanda datang ke Indonesia dan ratusan tahun berinteraksi, menghasilkan percampuran kebudayaan, yang salah satunya adalah perkembangan karya sastra Jawa. Karya 
sastra yang dahulu berbentuk tembang dan berisi ajaran hidup kini berbentuk prosa dan terbebas dari aturan-aturan penulisan dan isi yang semakin sederhana dan ringan. Karya sastra berbahasa Jawa pertama yang berbentuk prosa adalah Serat Rijanta, ditulis oleh R. Sulardi (diterbitkan oleh Balai Pustaka pada tahun 1920 setebal 139 halaman). Serat Rijanta mengawali tulisan yang tidak memiliki misi untuk menyampaikan ajaran moral tertentu (Ras, 1985: 13). Selanjutnya, sastra majalah lebih berkembang setelah bermunculan majalah berbahasa Jawa, salah satunya adalah Panjebar Semanagat.

Hutomo (1976) menjelaskan bahwa pada awalnya, Dr. Soetomo menerbitkan majalah mingguan bernama Soeloeh Ra'jat Indonesia dan majalah bulanan Kromo Duto yang berbahasa Melayu. Kromo Duto kemudian berubah menjadi Soeara Oemoem yang kemudian terbit tiap minggu. Pada tahun 1931, majalah mingguan Soeloeh Ra'jat Indonesia dan Soeara Oemoem bergabung menjadi Soeara Oemoem yang memiliki 12 halaman, delapan lembar yang berbahasa Melayu dan empat lembar berbahasa Jawa. Pada 2 September 1933 berubah menjadi Panjebar Semangat dan mulai berbentuk buku pada 7 September 1935 (Hutomo, 1976: 12-13). Panjebar Semangat yang hingga kini masih bertahan, tetap menampilkan berita dan pengetahuan-pengetahuan lain serta geguritan (puisi berbahasa Jawa) dan cerita-cerita fiksi berupa cerbung (cerita bersambung) dan cerkak (cerita cekak atau cerita pendek) untuk dewasa, horor, remaja dan anak-anak).

Karya sastra berbahasa Jawa memiliki peminat yang segmentif dengan kegemaran membaca masing-masing rubrik yang disukai, salah satunya adalah rubrik "Alaming Lelembut." Tidak diketahui kapan pertama kali rubrik ini muncul dalam majalah Panjebar Semangat. "Alaming Lelembut” menampilkan cerita yang menegangkan dan kadang-kadang berisi narasi-narasi yang seksi serta dihiasi romantisme sepasang kekasih. Hantu-hantu yang ditampilkan dalam rubrik ini juga beragam, mulai dari hantu-hantu lokal seperti kuntilanak dan genderuwo hingga zombie (Panjebar Semangat, 3 Oktober 2014). Penelitian ini menggunakan objek material cerita-cerita "Alaming Lelembut" yang terdapat dalam majalah Panjebar Semangat tahun 2013. Terdapat 52 cerita pendek pada rubrik "Alaming Lelembut" dan 27 cerita yang menampilkan hantu perempuan sebagai tokoh utama dan enam cerita yang dijadikan sampel pada penelitian ini. Keenam cerita tersebut adalah "Peri Pasar" tulisan Sutramanto, “Kumarane Komariah" tulisan Sriyono R, “Kijing Miring” tulisan Winongwong Sih, "Mantenan Lan Maesan" tulisan Sri Adi Harjno, "Kubur Nyai Jingkrak" tulisan FX Subroto dan "Wanita Ayu Ing Njero Sumur" tulisan FX Subroto.

\section{Horor Alaming Lelembut}


Cerita horor merupakan salah satu genre cerita yang digemari oleh kalangan terbatas namun dengan fanatisme yang tinggi. Penikmat cerita horor menyukai perasaan takut dan bergidik yang mereka alami ketika mengapresiasi cerita yang menakutkan bahkan tentang sesuatu yang belum pernah mereka alami dan ketahui sebelumnya. Cawelti mengemukakan pendapatnya seperti berikut ini.

" ... horror is the most puzzling sort of entertainment, yet, judging from immense popularity of the formula and the great enjoyment audience derive from it, people take enormous delight in being scared out of their wits, at least in fantasy (Cawelti, 1976: 47).

"Alaming Lelembut" menampilkan hantu perempuan dalam wujud yang berpola, yaitu terlihat begitu cantik dan menarik pada awalnya kemudian seketika berubah menjadi seram dan membawa kemalangan. Interaksi mereka dengan manusia disebabkan oleh hal yang beragam, seperti yang dijelaskan oleh Djokosujatno berikut ini.

"Cerita hantu menekankan interaksi antara manusia dan hantu atau makhluk supranatural lainnya, biasanya karena ada urusan: ada hal yang tak dapat diselesaikan oleh manusia sebagai manusia atau hantu sebagai hantu. Mereka berinteraksi karena terpaksa, terjebak dalam suatu keadaan yang salah tetapi bisa juga karena suatu perasaan tertentu si hantu terhadap manusia. ... umumnya adalah mantan manusia. Manusia yang mati tidak sewajarnya atau yang ketika hidup bergelimang dosa" (Djokosujatno, 2005: 77-78).

Kutipan di atas diungkapkan oleh Apsanti Djokosujatno dalam bukunya Cerita Fantastik yang juga membahas tentang cerita horor. Interaksi yang terjadi antara hantu perempuan dan manusia laki-laki dalam cerita "Alaming Lelembut" kebanyakan terjadi karena hantu perempuan menampakkan diri atau menjelma menjadi sosok manusia terdekat yang telah dikenal.

"Dalam cerita hantu Indonesia umumnya berbentuk manusia atau mendekati manusia ... . Tokoh hantu dalam cerita hantu biasanya tampil mempunyai unsur-unsur fisik yang menakutkan, bertampang buruk atau menakutkan tetapi bisa juga sebaliknya luar biasa cantik atau tampan atau tidak berwujud sama sekali" (Djokosujatno, 2005: 79).

Dalam penelitian ini, hantu perempuan pada awalnya menjelma menjadi sosok yang cantik dan menarik kemudian seketika berubah menjadi mengerikan bahkan membawa kemalangan. Sosok perempuan mengerikan yang muncul merupakan perwujudan dari alam bawah sadar manusia tentang hal-hal yang selama ini terpendam. Seperti yang dikatakan oleh Noel Carroll dalam esainya yang berjudul "The Phillosophy of Horror" sebagai berikut.

"... virtually, axiomatically that if a horrific creature can be designated as a figure of a repressed physic material that will, in turn, support an explanation of the way in which the figure yields pleasure through manifesting what is repressed" (Ashley, 1997: 182). 


\section{Arwah dalam Budaya Jawa}

Niels Mulder menjelaskan bahwa pikiran kejawen mempunyai suatu ciri religius mendalam, yaitu kesadaran bahwa semua yang ada turut ambil bagian dalam kesatuan eksistensi serta ketergantungan pada suatu prisip kosmis yang meliputi segala-galanya dan yang mengatur hidup manusia (Mulder, 1983: 61). Hal ini terbukti pada slametan (slametselamat, sebutan untuk upacara tradisional Jawa) yang dilakukan oleh orang Jawa. Menurut Beatty "the slametan, a ceremonial meal consisting of offerings, symbolic foods, a formal speech, and a prayer ... “ (Beatty, 2003: 25). Slametan dilakukan dengan segenap pengharapan untuk memperoleh keselamatan dan kelancaran dalam kehidupan sehari-hari.

Ketika slametan berlangsung, masyarakat diharuskan untuk menjaga lisan dan sikap. Menurut Clifford Geertz ... There is always the polite, embarrassed, muted manner which suggests that, despite the brevity and lack of drama the ritual displays, something important is going on (1976: 11-12). Dia menambahkan bahwa yang mendasari masyarakat Jawa melakukan slametan adalah seperti dalam kutipan di bawah ini.

"... at slametan, everyone is treated the same. The result is that no one feels different from anyone else, no one feels lower than anyone else, and so no one has a wish to split off the other person. Also after you have given slametan, the local spirits will not bother you, will not make you feel ill, unhappy or confussed" (Geertz, 1976: 14).

Oleh karena itu, slametan menjadi salah satu tanda masyarakat Jawa yang menginginkan terciptanya kerukunan, baik dengan sesama manusia atau dengan arwah yang hidup di sekitar lingkungan tempat tinggal mereka. Masyarakat Jawa juga mempercayai waktu-waktu tertentu ketika arwah keluar dari tempat tinggalnya.

"This (sunset), perhaps reflects the belief that the period during which the sun is setting is an especially dangerous one so far as the spirits are concerned, for, like the Javanese themselves, the spirits are all out wandering about and visiting their friends at this time ... ." (Geertz, 20: 1976).

Masyarakat Jawa secara garis besar mempercayai jenis-jenis arwah berikut ini.

1). Memedi (frightening spirits) adalah arwah yang menakut-nakuti tanpa meninggalkan kerusakan yang berarti. Genderuwo, wewe, jrangkong, wedon, banaspati, jin, pisacis, uwil, setan gundul, sundel bolong (Geertz, 1976: 17-18).

2). Lelembut (posessing spirits) adalah arwah yang mampu merasuki atau menyebabkan sawan (sakit yang tidak jelas penyebabnya), kegilaan bahkan kematian (Geertz, 1976: 19-21).

3). Tuyul (familiar spirits) adalah arwah yang berwujud sebagai anak kecil gundul yang ditugaskan oleh manusia untuk mencuri uang (Geertz, 1976: 21-23). 
4). Demit (place spirits) adalah jenis arwah yang menghuni sebuah tempat keramat tertentu (Geertz, 1976: 23-25).

5). Danyang (guardian spirits) hampir mirip seperti demit, menguasai suatu tempat keramat tertentu. Ia adalah yang pertama kali membuka lahan (mbabad) yang kelak digunakan untuk pemukiman warga (Geertz, 1976: 26-28).

\section{Perempuan dalam Budaya Jawa}

Masyarakat kebanyakan mempercayai jika perempuan diciptakan dari tulang rusuk laki-laki, seperti yang telah diceritakan dalam kitab suci. Hal ini mengakibatkan perempuan menjadi pihak yang dinomorduakan sampai pada bentuk-bentuk aktivitasnya pun berada di bawah kekuasaan laki-laki. Dalam tradisi patriarkal, perempuan adalah milik (tanggung jawab) dari konsep laki-laki tertinggi yang ada di dekatnya, apakah itu ayah, suami, saudara laki-laki bahkan anak. Perempuan dalam bahasa Jawa disebut wanita yang merupakan jarwa dhosok (akronim) wani ditata, (tata-titi, tatas-titis, tatag-tutug), wani tapa (tapa-tapaktelapak), dengan kata lain, telapak kaki wanita diartikan sebagai eksistensi surga (Purwadi, 2005: 560). Wani yang berarti berani, ditata berarti diatur. Dalam hal ini perempuan adalah, sosok yang diobjektifikasi untuk memenuhi harapan-harapan dan keinginan dari budaya yang melingkupinya. Wani (berani) tapa (menderita) (Damardjati Supadjar melalui Handayani, 2004: 24) memiliki pengertian jika perempuan adalah sosok yang berani menderita bahkan demi orang lain (keluarganya). Perempuan menjadi pihak yang (dipaksa) paling berusaha untuk membahagiakan orang (keluarga) telah menjadi hal yang normal dalam masyarakat patriarkal. Sebagai contoh, perempuan tidak memiliki ruang dan kesempatan untuk mengembangkan diri karena telah disibukkan dengan urusan rumah tangga.

Perempuan berada dalam kebudayaan Jawa yang memakaikan "baju kebesaran" sebagai pihak yang berjalan di atas surga keluarganya dengan catatan menjadi anak perempuan yang baik, istri yang baik dan ibu yang baik yang mengesampingkan keinginan dan potensi dirinya sendiri. Dalam hal ini perempuan memiliki peran dalam masyarakat hanya dititikberatkan dari segi kewanitaannya dan melupakan segi kemanusiaan. Perempuan yang baik (dalam budaya patriarkhal) adalah perempuan yang menjadikan keluarga sebagai hal yang utama. Bahkan, perempuan dianggap sempurna jika telah melahirkan seorang anak dalam sebuah institusi perkawinan yang sah. Perempuan yang melahirkan anak di luar perkawinan yang sah (korban perkosaan, perempuan simpanan, pekerja seks) dianggap tidak memiliki kehebatan seperti yang dimiliki oleh seorang istri yang sah. Dapat dikatakan, bahwa perempuan dan anak bukanlah yang menjadi fokus pemberian gelar kesempurnaan kepada 
perempuan itu sendiri namun budaya patriarkhal-lah yang telah memberi batasan-batasan tertentu bagi perempuan, yang memisahkan mereka ke dalam status baik atau buruk.

Perempuan Jawa sering dilabeli dengan istilah kanca wingking (teman belakang) dan area belakang rumah yang lebih diasosiasikan dengan area untuk memproduksi makanan atau dhapur. Selain sebagai tempat untuk memproduksi makanan, dhapur juga berarti wajah (Utomo, 2009: 69). Dengan demikian, hal ini menggambarkan bahwa perempuan dalam rumah tangga merupakan refleksi wajah dari sebuah keluarga. Para perempuan terutama ibu dipandang sebagai simbol moralitas keluarga karena laki-laki telah menjadi simbol dunia luar yang harus ditaklukkan (Handayani, 2004:46). Hal ini merupakan hasil dari cara membesarkan anak, di mana orang Jawa terbiasa memanjakan anak laki-laki sembari mendisiplinkan anak perempuan (Mulder, 2006: 110).

Wanita Jawa memiliki julukan kanca wingking (menjadi teman saat di belakang rumah), masak (tugasnya memasak), manak (melahirkan anak), macak (berhias untuk suami), mlumah lan momong bocah (mlumah-terlentang, memenuhi kebutuhan seksual suami; serta mengasuh anak). Namun terdapat kata yang tidak disebut pada ungkapan tersebut, yaitu sakprayoganipun (prayoga = baik, pantas; sakprayoganipun = ketersepakatan, sepantasnya, disarankan agar baik, seyogyanya) (Utomo, 2009: 385). Oleh karena itu, aturan tersebut pada kenyataannya tidak dapat diterapkan secara kaku karena akan merusak tatanan (yang dipercaya oleh orang Jawa sebagai keselarasan hidup), ditambah lagi dengan daya terima orang Jawa yang tinggi. Jadi, pembagian tugas secara seksual menjadi bias hingga tak jarang pula menjumpai laki-laki yang turut mengerjakan pekerjaan rumah tangga atau perempuan yang membantu perekonomian keluarga.

Perempuan yang memiliki peran secara ekonomi dalam keluarga akan memiliki posisi yang sejajar dengan laki-laki. Pada jaman dahulu, hanya perempuan dari kalangan menengah ke bawah yang berhak (bahkan merasa wajib) untuk berpartisipasi dalam perekonomian yang distereotipkan hanya menjadi urusan laki-laki. Hal ini menyebabkan tidak ada lagi jurang pemisah antara laki-laki dan perempuan. Berbeda dengan perempuan kelas priyayi, yang tidak berkontribusi dalam perekonomian (karena sudah kaya) namun tidak mendapatkan kesetaraan dengan laki-laki. Anak perempuan kelas priyayi mendapatkan kesempatan untuk sekolah (seperti R. A. Kartini), sementara perempuan kelas bawah bekerja di pasar, perkebunan, sawah atau membuat peralatan dan kerajinan. Perempuan pada kelas bawah terbebas dari dominasi laki-laki bahkan dikatakan oleh Rogers (dalam Handayani, 2004: 5-6) bahwa dominasi laki-laki pada akhirnya hanya berhenti pada ideologi saja. Ketika 
dihadapkan dengan kenyataan maka dominasi laki-laki ini menjadi mitos. Dalam hal ini sekali lagi perempuan diukur keberhasilannya dari perannya dalam keluarga.

Dalam budaya Jawa terdapat mistifikasi terhadap sosok ibu, yang dianggap memiliki kekuatan magis karena darinyalah sumber kehidupan (rahim dan air susu) berasal. Oleh sebab itu, perempuan dilambangkan sebagai sosok kesuburan (Dewi Sri, Ibu Pertiwi dan lain-lain). Hal yang sama tidak terjadi kepada perempuan yang belum memiliki anak apalagi perempuan yang belum menikah. Masyarakat Jawa mempercayai bahwa perempuan adalah tanggung jawab dari sosok laki-laki terdekatnya, bisa suami, kakak, ayah atau anak mereka yang telah dewasa (dalam kaitannya dengan studi ini, semua tokoh hantu perempuan adalah lajang). Perempuan yang telah berada pada usia menikah namun belum juga menikah merupakan ancaman bagi tatanan (yang dijalankan oleh laki-laki) karena perempuan tersebut akan dianggap belum Jawa, belum memenuhi salah satu darmanya sebagai manusia (metu-lahir, manten-menikah, mati-meninggal) (Mulder, 1983: 35) karena kelajangannya.

\section{Femme Fatale}

Istilah femme fatale berasal dari bahasa Perancis femme dan fatale. Femme berarti (orang) perempuan, wanita (KPI, 2009: 430) dan fatale adalah mematikan, membawa kematian, membawa maut, mencelakakan, bencana, kemalangan (KPI, 2009: 425). Menurut kamus Webster (diakses 12 April 2014) femme fatale adalah "irresistibly attractive woman, especially one who lead men into danger or disaster". Bade (1979: 9) menggambarkan tentang femme fatale sebagai "woman as malignant, threatening, destructive and fascinating", sedangkan menurut Allen femme fatale adalah "she is a woman who lures man into danger, destruction, even death by means of her overwhelming seductive charms" (Allen, 1983: vii).

Pengertian di atas memberikan gambaran yang singkat tentang femme fatale, ciri-ciri dan akibat yang ditimbulkan terhadap laki-laki tanpa menyebut sebab, mengapa perempuan dapat digambarkan sebagai sosok yang membahayakan dan mencelakakan. Hal ini bisa disebabkan karena anggapan bahwa "perempuan adalah bahaya" telah berada dalam kesadaran masayarakat sejak waktu yang lama. Konsep femme fatale diungkapkan pertama kali oleh Mario Praz (1933: 189-190) sebagai berikut.

"there always existed fatale women both in mythology and literature, since mythology and literature are imaginative reflections of various aspect of real life, and real life has always provided more or less complete examples of arrogant and cruel females characters and that her image is more numerous during times in which the springs of inspiration were troubled." 
Femme fatale dapat dilihat dari dua perspektif yang berbeda, yaitu dari perspektif lakilaki dan perspektif perempuan. Femme fatale berperspektif perempuan kerap muncul dalam novel-novel Nawal El Saadawi seperti Perempuan Di Titik Nol (Saadawi, 2010), Memoar Seorang Dokter Perempuan (Saadawi, 1990), dan Two Woman In One (Saadawi, 1985). Tokoh Firdaus dalam Perempuan Di Titik Nol, tokoh utama wanita yang anonim dalam Memoar Seorang Dokter Perempuan dan Bahiah Shaheen dalam Two Women In One digambarkan sebagai perempuan cantik dengan masa kanak-kanak yang berat. Mereka hidup di lingkungan masyarakat yang menganggap kewanitaan sebagai aib dan merupakan hal yang patut untuk disembunyikan.

Dalam perspektif perempuan, femme fatale adalah buah dari represi yang diterima perempuan sejak masih anak-anak. Kewanitaan dinilai sebagai sesuatu yang sudah seharusnya disembunyikan agar tidak ada hal buruk yang terjadi. Sekalipun ada hal buruk yang terjadi, kesalahan dilimpahkan kepada perempuan yang dianggap liar, menggoda dan tidak mampu menjaga dirinya (misalnya dalam kasus pelecehan seksual dan perkosaan). Selanjutnya akan dijabarkan tentang femme fatale dalam perspektif laki-laki, mengingat cerita yang dianalisis hampir semuanya adalah hasil dari tulisan laki-laki.

Dalam mitos dan sastra, sosok perempuan pembawa bencana kerap sekali muncul seperti yang telah Praz katakan. Ibu dari semua femme fatale adalah Hawa (Edwards, 2010: 35) yang diperdaya oleh ular iblis untuk memakan buah terlarang. Ketidakpatuhan Hawa dan Adam, mengakibatkan mereka diusir dari surga untuk menjalani hidup di dunia. Oleh karena itu perempuan, dalam hal ini Hawa, dipersalahkan sebagai penyebab kesengsaraan yang dialami oleh mereka berdua.

Representasi lain dari Femme Fatale adalah Judith, Jezabele, Delillah dan Salome. Dalam budaya Romawi terdapat nama-nama seperti Helen of Troy, Pandora, Circe, Medusa, Medea dan Sirens. Siren adalah mahluk mitologi yang beada di laut yang mengacaukan arah pelaut kemudian menenggelamkannya. This fate (drowning) can be interpreted and councious metaphor for a men's fear of being overwhelmed by female sexuality, or for lost of identity and self control in sexual intercourse (Bade, 1979:8). Helen of Troy diceritakan sebagai penyebab perang Troy karena menjadi sengketa atas raja Sparta dan Troy. Venus hidup di abad pertengahan sebagai seorang penjahat pada legenda Tanhauser. Pandora diceritakan mirip dengan Hawa, Pandora membuka kotak terlarang pemberian Zeus yang berisi penderitaan, penyakit dan kesengsaraan yang akhirnya jatuh menimpa manusia.

Sosok femme fatale dalam budaya Jawa terdapat pada Shinta, Ken Dedes, dan Rara Jonggrang. Shinta diceritakan sebagai sumber malapetaka, yang menimpa Rama, suaminya 
dengan Rahwana yang jatuh cinta kepadanya. Pertarungan ini menyebabkan matinya Rahwana dan hancurnya kerajaan Alengka oleh Rama yang dibantu oleh pasukan kera (Sudibyoprono, 1991: 480-482). Kisah lainnya, Ken Dedes anak pendeta Budha yang dinikahi secara paksa oleh Tunggul Ametung. Tunggul Ametung terbunuh oleh pengawalnya sendiri, Ken Arok karena memperebutkan Ken Dedes. Ken Arok pun akhirnya terbunuh oleh anak Tunggul Ametung, Anusapati yang masih dalam kandungan Ken Dedes saat Tunggul Ametung terbunuh. Kisah lainnya adalah Rara Jonggrang, putri raja raksasa bernama Raja Baka yang terbunuh oleh Pangeran Bandung Bandawasa, putra mahkota kerajaan Pengging. Bandhung Bandawasa kemudian ingin menikahi Roro Jonggrang, tapi diberi syarat untuk membangun seribu candi sebelum matahari terbit, Bandhung Bandawasa menyanggupinya. Rara Jonggrang berusaha menggagalkan usaha Bandhung Bandawasa dengan membangunkan para perempuan desa. Mereka segera memukul lesung untuk membangunkan ayam yang kemudian segera berkokok tanda pagi.

Sosok femme fatale yang selain diceritakan hidup sebagai manusia ada pula yang hidup di luar dunia manusia. Mereka adalah Sphinx, Siren, Medusa di barat dan Nyi Rara Kidul, Sundelbolong dan Kuntilanak di Jawa. Sphinx adalah perempuan berkepala dan berdada manusia, sedangkan bagian bawah tubuhnya adalah serangga, ular, reptil atau sejenis kucing. Menurut Bade, Siren adalah perempuan setengah burung atau setengah duyung bersuara merdu. Jika para pelaut mendengar suara Siren maka kapal akan karam dan mereka akan mati (Bade, 1979: 8). Sedangkan Medusa adalah dewi rupawan yang diharuskan hidup selibat, namun dia bersama Poseidon melakukan hubungan suami istri di kuil Athena. Oleh karena itu, Medusa kemudian dihukum menjadi monster mengerikan berambut ular (greekmythology.com). Dalam budaya Jawa, Nyi Roro Kidul diceritakan sebagai penguasa pantai selatan, dan disejajarkan dengan sosok Dewi Sri. Bahkan Nyi Roro Kidul dikisahkan sebagai pasangan spiritual raja-raja Jawa. Nyi Roro Kidul saat menjadi istri raja Jawa berwujud sebagai perempuan cantik di siang hari dan perempuan tua di malam hari. Namun ketika muncul di laut, sering muncul juga dengan seekor ular raksasa (Triwikromo, 2006: 146). Sundelbolong dikisahkan sebagai pelacur semasa hidupnya atau perempuan hamil yang bunuh diri (Siddique, 2002: 26). Setelah meninggal arwahnya gentayangan dan menakutnakuti manusia terutama laki-laki. Sedangkan Kuntilanak adalah perempuan yang meninggal saat atau setelah melahirkan. Ia mencuri bayi baru lahir lalu membawanya terbang dari satu pohon ke pohon lain.

Helen of Troy, Ken Dedes, Shinta dan Rara Jonggrang dilanggengkan oleh sejarah menjadi penyebab perselisihan laki-laki. Perempuan dijadikan piala atau simbol kekuasaan 
hingga patut untuk diperebutkan. Selain kekuasaan, perempuan juga menjadi properti yang digunakan laki-laki untuk menunjukkan kejantanannya. Pihak yang pada akhirnya memiliki kuasa atas perempuan maka ialah pemenangnya. Apakah Sparta atau Troy, Tunggul Ametung atau Ken Arok, Rahwana atau Rama, atau kah Raja Baka atau Bandhung Bandawasa.

Sphinx, Siren dan Medusa, diwujudkan sebagai mahkluk setengah manusia dengan setengah lagi hewan. Hal ini menunjukkan bahwa makhluk tersebut adalah representasi dari sisi kebinatangan dari perempuan yaitu liar, ganas dan tidak berperasaan (Bade, 1977: 9). Hal tersebut juga berlaku pada Nyi Roro Kidul, yang muncul bersama ular raksasa. Ular adalah lambang dari alat kelamin laki-laki, juga berarti phallus. Medusa. Sphinx, Siren dan Nyi Roro Kidul adalah representasi dari ketakutan laki-laki dengan nafsunya sendiri, takut untuk kehilangan kendali dan menanggung konsekuensi yang terjadi. Perempuan dengan air juga menjadi metafora alam bawah sadar laki-laki atas ketakutannya menjadi tenggelam dalam menghadapi seksualitas perempuan atau kehilangan identitas serta kuasa saat berhubungan seksual (Bade, 1977: 9).

Hal yang tidak jauh berbeda terjadi pada Sudelbolong yang menjadi citra perlawanan perempuan terhadap tatanan masyarakat. Sundelbolong memiliki kuasa atas dirinya sendiri, dengan kata lain tidak bergantung pada sosok laki-laki. Idealnya, perempuan selalu berada dalam hubungannya dengan sesuatu (keluarga, komunitas, negara) atau seseorang (anak, suami, bapak) (Suryakusuma, 2011: 3). Sundelbolong (dan hantu perempuan lainnya) adalah oposisi biner dari sosok perempuan ideal di mata laki-laki, dia bebas mengekspresikan diri, abai dengan penampilan, menuruti hawa nafsu, sensual dan menggoda. Dalam penelitian ini, yang menjadi titik perhatian adalah femme fatale yang sejenis dengan Sudelbolong.

Seksualitas perempuan yang terbebaskan ketika telah menjadi arwah menunjukkan bahwa semasa perempuan tersebut hidup, selamanya berada dalam budaya yang mengharuskan perempuan untuk menyembunyikan seksualitasnya. Sementara laki-laki menggunakan aturan ini untuk melanggengkan kekuasaan dan kontrol atas perempuan. Mulai dari kehidupan sehari-hari, anak perempuan diberi pengertian bahwa perbedaan kelamin membawa perbedaan hak dan kewajiban (bertentangan dengan teori feminisme yang memperjuangkan kesetaraan). Tidak hanya aturan, perempuan juga diikat dengan pelbagai mitos tabu mengenai seksualitasnya, salah satunya adalah tabu keperawanan dan menstruasi. Sanksi paling berat adalah hukuman masyarakat, berlaku jika perempuan melanggar aturan tersebut. Perempuan dianggap melanggar kodratnya (yang diciptakan oleh laki-laki) dan diganjar dosa yang amat besar. Idealnya (di mata laki-laki) perempuan adalah yang frigid, yang meredam nafsunya dan patuh dengan norma sosial. Di mata masyarakat, perempuan 
yang melanggar norma-norma sosial adalah perempuan nakal dan mendapatkan posisi yang paling rendah dalam strata sosial masyarakat.

Dalam hal ini, seksualitas menjadi hal yang paling dilihat karena menyita perhatian laki-laki atas perempuan, seakan-akan mereka lupa bahwa perempuan juga manusia. Nilai perempuan sebagai manusia direduksi sebagai payudara, vagina atau rahim yang mampu berbicara. Hal ini disebabkan oleh ketakutan laki-laki atas nafsunya sendiri jika dihadapkan dengan seksualitas perempuan. Ketakutan laki-laki jika sampai tenggelam dalam seksualitas perempuan, dan hilangnya status laki-laki sebagai penakluk perempuan. Dengan demikian, femme fatale adalah perlawanan perempuan atas dominasi laki-laki yang direpresentasikan oleh hantu perempuan.

\section{Tipe-tipe Hantu Perempuan}

\section{1. Hantu Perempuan yang Semasa Hidupnya Baik}

Tipe perempuan baik dalam "Alaming Lelembut” tahun 2013 terdapat dalam beberapa cerita, di antaranya adalah "Kumarane Komariah" tulisan Sriyono R dan "Mantenan Lan Maesan" tulisan Sri Adi Harjono. Kedua cerita dianalisis berdasarkan pemicu hantu perempuan menjadi femme fatale melalui kutipan yang dirasa paling mewakili. Berikut ini adalah kutipan dari cerita yang berjudul "Kumarane Komariah."

Wekasane Mat Rojali kawin meneh karo prawan asal Tasik. Jenenge Sukesih. Durung gantalan taun dadi bojone Mat Rojali, Sukesih mbobot, sing njalari Mat Rojali nglalekake Kokom" (Sriyono, 2013: 5).

("Sudah lima tahun berumah tangga namun tak kunjung dikaruniai momongan. Hal itu yang menjadi alasan bagi Mat Rojali untuk menikah lagi dengan perawan asal Tasik. Namanya Sukesih. Belum sempat tahun berganti Sukesih menjadi istri Mat Rojali, Sukesih hamil. Hal itu yang menyebabkan Mat Rojali melupakan Kokom.”)

Komariah hanya dihargai sebagai patner seksual dan penerus keturunan. Komariah mandul, oleh karena itu dia dinilai pantas oleh suaminya yang bernama Mat Rojali untuk dimadu. Setelah menikah dengan Sukesih yang dengan cepat dapat memberikan keturunan, fungsi Komariah sebagai patner seks Mat Rojali telah tergantikan oleh istri barunya. Menikah lagi dinilai sebagai jalan keluar untuk memperoleh keturunan namun perlu dipertanyakan motivasi Mat Rojali menikah dengan perawan yang belum terbukti dapat memberikan keturunan. Indikasi yang paling besar adalah Mat Rojali ingin membuktikan maskulinitas atau kejantanannya dengan menaklukkan tidak hanya satu perempuan dan membuktikan bahwa dirinya dapat melanjutkan dominasi tidak hanya atas perempuan-perempuan tapi atas 
anak juga. Komariah yang tersiksa dengan kemalangan yang dialaminya, memilih jalan pintas yaitu bunuh diri dengan meminum racun.

Hal yang tak jauh berbeda terjadi pada Romlah dalam Mantenan Lan Maesan. Romlah meninggal karena pendarahan hebat pada malam pertamanya setelah menikah dengan Rohmadi. Kutipan berikut ini menunjukkan hal tersebut.

"Bareng intuk ketrangan saka juragan Nursalam kanthi tlesih, dhoktere banjur gawe dhudhutan. Jiwa lan sukmane Romlah nulak yen nganti 'keprawane' dirampas dening wong kang oran ditresnani. Mahanani otot-otot awake dadi kaku lan atos. Kelebu otot pinggul lan pawadone. Sarehne dirudha peksa, dheweke kendhangan keprawanane Romlah rusak kang banget nemene nganti pembuluh darahe pecah. Saengga ngalami 'pendarahan' ngono iku" (Harjono, 2013: 27).

("Setelah mendapatkan keterangan dari Juragan Nursalam secara rinci, dokter lalu membuat kesimpulan. Jiwa dan tubuh Romlah menolak jika keperawanannya dirampas oleh orang yang tidak dia cintai. Sampai otot-otot di tubuhnya kaku dan mengeras. Termasuk otot pinggul dan kewanitaannya. Layaknya perempuan yang diperkosa, dokter berkata bahwa selaput dara yang dimiliki oleh Romlah rusak berat hingga pembuluh darahnya pecah. Sehingga mengalami pendarahan seperti itu.)

Kutipan di atas menunjukkan Romlah yang terpaksa menikah dengan pria pilihann ayahnya. Namun ketika dihadapkan dengan Rohmadi, Romlah tidak dapat menutupi perasaan yang sesungguhnya. Romlah tidak mencintai Rohmadi hingga tubuhnya menolak untuk melakukan hubungan suami istri. Namun yang terjadi, Rohmadi memaksakan kehendaknya atas tubuh Romlah. Dengan demikian, Romlah sebagai perempuan telah mengalami ketertindasan atas haknya dua kali. Pertama ketika ayahnya menikahkan dirinya dengan pria yang bukan pilihannya dan tanpa meminta persetujuannya terlebih dahulu. Kedua, ketika Rohmadi dengan paksa melakukan aktivitas seksual terhadap tubuh Romlah. Jadi, hal yang menimpa Romlah adalah gambaran perempuan yang tidak memiliki hak atas tubuhnya sendiri karena dalam masyarakat patriarkhal perempuan merupakan tanggung jawab (properti) dari sosok laki-laki yang terdekat dengannya.

\section{2. Hantu Perempuan yang Semasa Hidupnya Tidak Baik}

Tipe perempuan yang kedua adalah perempuan yang semasa hidupnya sensual dan menuruti hawa nafsu. Cerita Peri Pasar tulisan Sutarmanto dan Kubur Nyai Jingkrak tulisan FX Sobroto menunjukkan hal tersebut melalui kutipan berikut ini.

"Yu Salinar sing ninggal amarga nggayut tuwuh nalika nandang wiring slingkuh karo tukang sapu pasar" (Sutarmanto, 2013: 2).

("Yu Salinar yang meninggal karena memadu kasih ketika berselingkuh dengan tukang sapu pasar.")

Dalam kutipan cerita di atas dikisahkan bahwa hantu perempuan jahat semasa hidupnya adalah perempuan yang tidak mampu menjaga diri dan tidak mampu menahan hawa nafsu 
untuk tidak selingkuh. Dapat diketahui bahwa hanya pihak perempuan yang diceritakan sebagai pihak yang jahat dan tidak bermoral namun pihak laki-laki (tukang sapu pasar) dibebaskan begitu saja dari stigma buruk masyarakat. Hal ini terjadi karena masyarakat menilai tabiat selingkuh yang dilakukan oleh laki-laki adalah hal yang biasa dan patut untuk dimaklumi. Hal yang tidak setara terjadi pada perempuan karena perempuan oleh masyarakat dilabeli dengan pengharapan-pengharapan yang merepresi perempuan sebagai manusia. Salah satunya adalah beban moral untuk menjaga kesucian dan kesetiaan dengan sanksi masyarakat yang lebih berat daripada sanksi untuk laki-laki. Tidak jauh berbeda dengan "Kubur Nyai Jingkrak," tokoh utama wanita bahkan dikatakan sebagai wanita hiper seks seperti yang ditunjukkan oleh kutipan berikut ini.

"Nyai Jingkrak mono mbiyen nalika urip mujudake sawijining wanita hiper sex. Seneng ngumbar nafsu, ngadani sesambungan badan karo sawenehe wong lanang sing gelem ngladeni. Mbok menawa wae, arwahe durung antuk papan kang semesthine, satemah kadhang isih seneng nggodha wong lanang sing lagi kasepen, ... ”(Subroto, 2013: 39).

("Begitulah Nyai Jingkrak, perempuan hiper seks semasa hidupnya. Gemar mengumbar nafsu, berhubungan badan dengan setiap laki-laki yang dengan senang hati melayaninya. Bisa jadi arwahnya belum menemukan tempat yang semestinya karena masih suka menggoda lakilaki kesepian ....")

Kutipan di atas menunjukkan bahwa Nyai Jingkrak semasa hidupnya adalah perempuan sensual yang tidak merasa tabu untuk menunjukkan nafsu birahinya padahal kebiasaan dalam masyarakat adalah sebaliknya. Perempuan diharuskan untuk menyembunyikan sensualitasnya dengan bermacam-macam aturan yang ada dengan sanksi sosial yang menjadi ancamannya. Perempuan yang demikian merupakan korban standar ganda yang dilabelkan kepadanya yaitu ketika perempuan harus menjaga diri dan kehormatannya dari dunia luar terutama lawan jenis namun laki-laki tidak harus begitu. Jika perempuan melanggar aturan tersebut maka dia mendapatkan sanksi sosial, sedangkan jika laki-laki yang melanggar, dia mendapatkan pemakluman yang kemudian mudah dilupakan oleh masyarakat.

Terdapat satu lagi tipe hantu perempuan yaitu yang tidak diketahui kisahnya selama masih hidup (“Kijing Miring” dan "Wanita Ayu Ing Njero Sumur”) namun tetap memberikan kemalangan bagi laki-laki. Oleh karena itu, analisis dilakukan pada bab-bab berikutnya.

\section{Bentuk Godaan yang Dilakukan Hantu Perempuan}

Tidak seperti cerita-cerita "Alaming Lelembut" lainya, dalam cerita "Mantenan Lan Maesan" hantu perempuan telah mengenal korbannya dengan baik karena Aris adalah lakilaki yang paling Romlah cintai.

"Mengko mampir omahku dhisik. Aku wis digawekake omah dhewe. Nek Arum lan Hardi mantenan ning omahe, aku karo kowe kudhu mantenan dhisik ning omahku. Lebar 
kuwi mangga yen arep bali", panjaluke Romlah karo lendhetan baune Aris. Aleman, ngadiadi." ... "Aris banjur dirangkul Romlah, diruket kenceng lan dibrukake ning ranjang. Nunggal turu!" (Harjono, 2013: 27).

(“"Nanti mampir dulu ke rumahku. Aku telah dibuatkan rumah sendiri. Jika Arum dan Hardi (adik dan ipar Aris) menikah di rumahnya sendiri, aku dan kamu harus menikah dulu di rumahku. Setelah itu terserah jika ingin pulang." Permintaan Romlah sembari menyandarkan kepalanya ke bahu Aris. Manja, menjadi-jadi." ... "Aris lalu didekap oleh Romlah, dipeluk begitu erat kemudian direbahkan ke ranjang. Mereka menyatu dalam persetubuhan!”).

Pada kutipan di atas terlihat betapa Romlah ingin menikah dengan Aris yang sangat dia cintai. Ketika bertemu dengan Aris, Romlah merasa bahagia dan seperti menemukan dirinya sendiri. Hal ini terlihat ketika dia bebas mencintai dan melakukan hubungan suami istri dengan Aris. Romlah melakukan hal tersebut dengan sukacita karena dia melakukan sesuatu yang menjadi hasil dari keputusannya sendiri. Semasa hidup, nasib Romlah ditentukan oleh sosok ayah dan suami. Namun setelah dia meninggal dia mampu melakukan hal-hal yang tidak dapat dilakukannya ketika masih hidup.

Jika dalam cerita "Mantenan Lan Maesan" sosok laki-laki yang menjadi korban hantu wanita adalah laki-laki yang baik, maka berbeda dengan yang terdapat pada "Peri Pasar." Tokoh pria dalam cerita ini adalah pencari masalah yang ingin membuktikan kebenaran sosok hantu pasar.

"Mas, sliramu iki piye ta? Aku iki rak bojomu ta? Sigaring uripmu. Mosok nantangnantang. Hara sawangen sing cetha, aku iki sapa. Aneh, karo bojo kok ngancam. Gek ngapa nganggo cucul kathok klambi barang kuwi. Kaya wong gendheng. Apa aku wedhi mbok wudhani?" (Sutarmanto, 2013: 2).

("Mas, kamu ini kenapa sih ? Aku ini istrimu kan? Belahan jiwamu. Masa sih kau tantang-tantang. Coba lihatlah yang jelas, aku ini siapa. Aneh, dengan istri sendiri kau tega mengancam. Lalu mengapa kau lepas baju dan celanamu itu. Seperti orang sinting. Kau pikir aku takut jika melihatmu telanjang?")

Kutipan di atas menunjukkan ketika sosok istri tokoh utama pria menghampiri suaminya di pasar. Terkejut dengan yang dilihat, tokoh utama pria melakukan tindakan yang sudah dia rencanakan sebelumnya. Tokoh utama pria beranggapan jika dia menanggalkan pakaiannya maka makhluk halus tidak akan menyakitinya. Karena terkejut dengan suara Sriasih, tokoh utama seketika melepaskan semua pakaiannya karena mengira suara tersebut adalah suara Peri Pasar Salinar. Tanpa pikir panjang, tokoh utama pria menuruti segala permintaan Sariasih yang sebenarnya adalah hantu perempuan yang sedang menjelma menjadi istinya.

“... kandane wanita ayu mau kang omongane malih dadi ngoko, ora basan-basan meneh." ... "Wong wadon ayu kang sakawit solah tingkahe sopan lan kebak subasita, malih dadi agresif banget. Kaya wong wadon hiper sex kang suwe ora kesenggol wong lanang. Njejeri lungguh ing sofa mepet-mepet awake Karsono"(Subroto, 2013:49). 
(“ ... ujar perempuan cantik tersebut, cara bicaranya berubah jadi kasual, bukan basabasi lagi." ... "Perempuan cantik yang beberapa saat lalu berperilaku sopan dan penuh kesantunan berubah menjadi agresif sekali. Layaknya perempuan hiper seks yang telah lama sekali tak mendapatkan sentuhan laki-laki. Duduk bersebelahan dengan Karsono merapatrapatkan tubuhnya.")

Dapat dilihat berdasarkan kutipan narasi cerita yang berjudul "Kubur Nyai Jingkrak" di atas bahwa perempuan tersebut berubah menjadi agresif bahkan layaknya perempuan hiper seks dan haus belaian laki-laki. Telah diceritakan sebelumnya bahwa Karsono sedang ditinggalkan oleh istrinya dan hidup sendiri selama hampir sebulan dan masalah terbesar yang dia hadapi adalah tidak terpenuhinya kebutuhan biologis. Karsono masih muda dan baru dua tahun menikahi Munaroh, masih dikuasai oleh darah mudanya yang berapi-api.

Cerita yang berjudul “Wanita Ayu Ing Njero Sumur" menampilkan bentuk godaan yang berbeda karena para tokoh utamanya hanya merasakan tanpa melihat sosok hantu perempuan yang telah mencelakai mereka.

“ ... Tarko crita. Ning njero sumur mau aku diruket uwong. Rasaku sing nyikep sawijining uwong wadon. Tangane alus, resik lan kuning nemu giring." ... "'Hah? Kowe ing njero sumur diruket wong wadon?! Lha kok padha karo aku. Aku mau ya diruket kenceng banget.' Kandhane Tasim nambahi critane Tarko"' (Subroto, 2013: 51).

(“... Tarko bercerita. Di dalam sumur, aku tadi didekap seseorang. Yang kurasakan, perempuanlah yang telah mendekap tubuhku. Tangannya halus, bersih dan warnanya kuning seperti temu giring." ... " Hah? Kau di dalam sumur didekap seorang perempuan?! Lha kok sama denganku. Aku juga didekap erat sekali tadi.' Kata Tasim menimpali cerita dari Tarko.")

Tidak hanya Tarko, ternyata Pak Tasim juga mengalami hal yang serupa, didekap seseorang dengan begitu kencang. Orang yang mendekap Pak Tasim dan Tarko adalah perempuan yang Tarko ceritakan memiliki tangan yang bersih dan halus yang kemudian mendapat pengiyaan dari Pak Tasim.

\section{Dampak yang Ditimbulkan oleh Hantu Perempuan Terhadap Korbannya}

Bermacam-macam kemalangan yang ditimbulkan oleh hantu perempuan, salah satunya seperti yang terdapat dalam cerita "Kumarane Komariah" tulisan Sriyono R berikut ini.

"Damar tedhas kena godha kumarane Komariah nganti nindakake saresmi kaya wong bebojowan, bareng kejodheran ngerti yen Kokom kuwi bangsa alus, Damar kaget dadi lara owah pikirane. Lha Hartati bojone Damar sing wektu kuwi lagi mbobot limang sasi, ngalami keguguran ..." (Sriyono, 2013: 5).

("Damar tergoda oleh arwah Komariah hingga melakukan hubungan badan layaknya suami istri. Setelah mengetahui bahwa Kokom adalah makhluk halus, Damar syok hingga membuatnya sakit jiwa. Sedangkan Hartati, istri Damar yang ketika itu sedang lima bulan mengandung, keguguran ...") 
Kutipan narasi yang dilakukan oleh Pak Haji Dolah mengungkapkan akibat bila seorang laki-laki tergoda Komariah. Damar menjadi gila setelah berhasil digoda oleh Komariah menunjukkan bahwa laki-laki dapat kehilangan kewarasan karena seorang perempuan. Laki-laki tersebut kehilangan kuasa atas dirinya sendiri dan dikuasai oleh satu hal yang memicunya menjadi gila, yaitu perempuan. Orang yang kehilangan kewarasan telah berada di luar lingkaran sosial masyarakat karena tidak dapat berperan di dalamnya. Oleh karena itu, dia tidak dapat didefinisikan secara sosial dan hukum yang berlaku dalam masyarakat. Dengan demikian, laki-laki yang pada masyarakat patriarkal berlaku aktif, terlempar dari posisinya semula menjadi tidak lagi memiliki hak dan kewajiban dalam masyarakat. Bahkan tidak lebih baik dari perempuan yang dinilai pasif, inferior, berstandar serta berperan ganda dan lain-lain.

Hartati yang keguguran menggambarkan perempuan yang kehilangan perannya untuk melanjutkan garis keturunan keluarga Damar. Calon ibu yang kehilangan janin dalam kandungannya menandakan bahwa dia tidak memiliki kapabilitas untuk menjadi ibu. Hal ini disebabkan perkembangan janin bergantung penuh kepada ibunya. Mulai dari asupan makanan dan penjagaan yang rahim ibu harus berikan bagi janin. Dengan demikian, sudah porak-poranda segala impian tentang keluarga yang bahagia bagi Damar dan Hartati. Tokoh utama dalam cerita yang hampir seluruh peristiwanya selalu berlangsung ketika malam hari ini adalah Komariah dan tokoh pria utama yang tidak disebutkan namanya. Komariah termasuk tokoh datar karena telah diceritakan sebagai sosok jahat dari awal sedangkan tokoh pria utama cenderung bulat karena pada tengah cerita dia dikisahkan hampir tergoda oleh Komariah.

Tak hanya pria asing yang mendapatkan akibat buruk yang diakibatkan oleh hantu perempuan, namun anggota keluarga yang pernah berlaku salah juga menjadi korban hantu perempuan. Berikut ini kutipan yang terdapat dalam cerita "Mantenan Lan Maesan" tulisan Sri Adi Harjono.

“ ... ujug-ujug juragan Nursalam weruh brebete Romlah kaya mlaku mapag lakune colt diesel. Mesti wae Romlah banjur ketabrak wong dheweke ora bisa nguwasani setir. Nanging saka kaca spion juragan Nursalam weruh Romlah mlaku lengket-lengket samburine colt diesel lan lap ilang kaya kesaput ing angin. Padha sakala juragan Nursalam semaput. Lan bareng sadhar dadi lumpuh. Kena stroke” (Harjono, 2013: 27).

(“ ... tiba-tiba Juragan Nursalam melihat penampakan Romlah seperti berjalan menghampiri laju Colt Diesel. Sudah barang tentu Romlah tertabrak karena dia tidak dapat menguasai kemudi. Namun dari kaca spion, juragan Nursalam melihat Romlah berjalan pelan selangkah demi selangkah di belakang Colt Diesel lalu lap! Hilang bagai tersapu angin. Seketika itu juga, juragan Nursalam pingsan. Kemudian ketika sadar, dia lumpuh. Terserang stroke.”) 
Kutipan di atas menunjukkan bahwa hantu perempuan tak hanya membawa kemalangan bagi kekasih yang pernah berlaku jahat kepadanya atau laki-laki yang baru ditemui, namun laki-laki yang masih memiliki hubungan darah juga terkena akibatnya. Dalam cerita Mantenan Lan Maesan, juragan Nursalam terkena serangan stroke yang menyebabkan kelumpuhan. Peristiwa dimulai ketika juragan Nursalam melihat Romlah, putrinya yang telah meninggal berjalan menghampiri mobil yang sedang dia dikendarai lalu seketika lenyap dari penglihatannya. Keterkejutan yang teramat sangat membuatnya kehilangan kesadaran kemudian terbangun dalam keadaan lumpuh karena stroke. Peristiwa tersebut dapat diartikan bahwa ketertindasan yang dialami perempuan dapat disebabkan oleh keluarganya sendiri dan tidak melulu didominasi oleh suami atau kekasih.

“... wayah bangun esuk Aris rumangsa kebrebegen pengocehe manuk nganti gragapan tangi. Bareng nyawang kiwa tengen, Aris gumun pungun-pungun. Kuburan!!! Lan kang sumandhing jroning turu dudu Romlah nanging maesan! Kelawan mambu-mambu wedi, Aris tumuli nyetitekake tulisan ing kijing kang isih katon remang-remang, 'Romlah Binti Nursalam" (Harjono, 2013: 27).

(“... waktunya bangun pagi, Aris merasa bising dengan suara burung hingga buru-buru bangun dari tidurnya. Ketika menyaksikan kanan dan kiri, Aris kaget setengah mati. Kuburan!!! Dan yang berada disampingnya bukan Romlah seperti semalam tapi nisan! Dengan laku takut-takut, Aris kemudian memperhatikan tulisan yang ada di nisan yang masih telihat lamat-lamat, 'Romlah Binti Nursalam'.’)

Kutipan di atas menunjukkan peristiwa yang terjadi sesaat setelah Aris terbangun dari tidurnya. Betapa terkejutnya dia ketika menyadari bahwa dia sedang berada di kuburan. Romlah yang semalam tidur dengannya ternyata sudah meninggal berdasarkan tulisan di sebuah nisan yang berada di sampingnya. Aris laki-laki baik yang begitu dicintai oleh Romlah sekalipun tidak lepas dari kesialan yang diakibatkan oleh hantu perempuan. Romlah terlihat hanya menuntaskan dendam cintanya kepada Aris karena semasa hidup mendapatkan tentangan dari ayahnya. Romlah juga kemudian tidak lagi diceritakan menggoda laki-laki atau membawa kemalangan bagi mereka. Tokoh-tokoh utama dalam cerita ini adalah Romlah dan Aris, keduanya termasuk tokoh datar karena tidak terdapat perubahan karakter dari awal hingga akhir cerita. Konflik yang terjadi dalam cerita ini antara Romlah dengan ayahnya yang menikahkan paksa, Rohmadi yang memaksanya berhubungan suami istri serta Aris yang terkejut setelah mengetahui bahwa Romlah ternyata telah meninggal.

Tak hanya sekali, hantu perempuan juga diceritakan kerap menggoda laki-laki mana saja tanpa alasan tertentu seperti yang terdapat dalam cerita "Peri Pasar" tulisan Sutarmanto berikut ini. 
"Jaka-jaka padha gila. Angger ana bocah lanang kemliwer ana ndalan mesti dicegat. Digeret tangane dijak ndelik ana petengan. Diblejeti pakeyane lan diodhos-odhos kanthongane. Sing bablas dadi korbane wes akeh. Kabeh ninggal, cangkeme ngumpluk. Kaya padha bar ngombe-ngombe oplosan. Pupune padha gosong-gosong. Gulune gosong-gosong. Dhengkule nglocop. Kabeh diweruhi wes ora nganggo awer-awer. Kathok karo klambine nglumbruk ana cedhake" (Sutarmanto, 2013: 2).

("Banyak pemuda ketakutan. Setiap ada pemuda melintas di jalan, pasti ia hadang. Diseret tangannya, diajak untuk bersembunyi dalam kegelapan. Dilucuti pakaiannya dan diporak-porandakan isi rongga dadanya. Sudah banyak yang menjadi korbannya. Semuanya meninggal, mulutnya berbusa. Mereka terlihat seperti telah minum miras oplosan. Paha mereka lebam. Leher mereka lebam. Lutut mereka seperti terbakar hingga terkelupas. Mereka semua ditemukan sudah tanpa busana. Pakaian mereka tergeletak di sebelah tubuh mereka.")

Keadaan korban-korban Salinar semuanya ditemukan dalam keadaan yang mengenaskan. Dikatakan di atas bahwa keadaan korban-korban Salinar nampak seperti korban meninggal karena minum miras oplosan. Hal ini menunjuKkan bahwa perempuan memiliki sifat memabukkan dan disejajarkan dengan alkohol. Keadaan tidak sadar (mabuk) dapat membuat orang melakukan apa saja tanpa merasa ada yang menghalangi termasuk norma-norma yang berlaku dalam masyarakat. Alkohol merusak kesehatan, itu pula yang ingin dikatakan oleh penulis bahwa perempuan bersifat merusak termasuk menghilangkan kesadaran laki-laki untuk melakukan hal yang melanggar norma-norma yang berlaku dalam masyarakat. Perlu pula diketahui bahwa sifat alkohol adalah mengakibatkan kecanduan. Dengan demikian, dapat diketahui bahwa sebenarnya laki-laki mengetahui kelemahan mereka terhadap perempuan namun masih saja terus menuruti hawa nafsunya untuk kemudian merasakan akibat yang merugikan diri mereka sendiri. Hal tersebut yang menjadi konflik dalam cerita ini, ketika tokoh pria utama resah dengan peri pasar yang akhirnya merugikan dirinya sendiri.

Cerita “Kijing Miring” tulisan Winongwong Sih menunjukkan akibat tak lazim yakni ketika hantu perempuan yang telah hidup bersama manusia laki-laki melahirkan anak. Jenis kelamin anak yang dilahirkan menentukan apakah manusia laki-laki tersebut harus mati atau dibiarkan tetap hidup oleh hantu perempuan. Berikut kutipan yang menunjukkan hal tersebut.

"... yen wes tekan titi mangsane laire si jabang bayi. Nanging, yen anake lair wadon, wong lanang kuwi bakal dialap patine. Ora liya kanggo maleni anake wadon mau yen wis diwasa. Yen anake lair lanang wong kuwi ora dikapak-kapakake" (Winongwong, 2013: 6).

("... ketika datang waktu lahir si jabang bayi. Jika anak yang dilahirkan adalah perempuan, laki-laki tersebut segera menemui ajal. Alasannya adalah untuk menjadi wali ketika bayi perempuan tersebut nanti dewasa. Jika yang lahir adalah bayi laki-laki, tidak terjadi apa-apa.")

Laki-laki yang hidup bersama peri tidak meyadari bahaya yang akan menimpanya. Yang menjadi klimaks dalam cerita ini adalah ketika peri melahirkan bayi perempuan karena 
bayi perempuan akan membutuhkan wali ketika dia dewasa kelak. Oleh karena itu, sang ayah harus bersamanya di dunia arwah, dengan kata lain harus mati. Namun jika anak yang dilahirkan adalah bayi laki-laki, sang ayah akan dibiarkan tetap hidup. "Mati" dalam hal ini dapat diartikan sebagai tidak adanya penyambung rantai keturunan keluarga (patriarkhal). Laki-laki merasa tidak memiliki agen melanggengkan kuasanya dan keperkasaannya terhadap perempuan dan dalam menurunkan penerus yang mereka nilai sebagai pemimpin. Hidup lakilaki yang diakhiri oleh perempuan yang melahirkan bayi perempuan dan baik-baik saja jika melahirkan bayi laki-laki dapat diartikan bahwa perempuan dalam hal ini bagaikan dua mata pisau. Di satu sisi, perempuan adalah pintu yang melanjutkan garis keturunan keluarga sedangkan di sisi yang lain, perempuan adalah pemutus rantai keluarga jika melahirkan bayi perempuan. Dengan kata lain, garis keturunan seorang laki-laki diputus (dibunuh) oleh istri dan anak perempuannya sendiri.

\section{Solusi}

Pada akhir cerita "Alaming Lelembut" terdapat pola yang selalu ada, yakni kemunculan orang "pintar" atau ahli agama. Berikut kutipan dalam cerita "Mantenan Lan Maesan" tulisan Sri Adi Harjono yang menujukkan hal tersebut.

"Wusana sorene, wayah bakda maghrib, Aris ngumpulake kanca-kancane santri saperlu tahlilan lan kirim donga amrih sukma nglembarane Romlah bali marang mulamulane. Nurut dalan sangkan paraning dumadi, ora kesasar lakune. Innalillahi wa inna ilaihi roji'un!" (Harjono, 2013:27).

("Waktu sore, ketika maghrib telah berkhir, Aris mengumpulkan teman-teman santrinya untuk tahlilan dan mengirimkan doa agar arwah Romlah yang masih gentayangan kembali ke asalnya. Melintasi jalan yang semestinya ketika dia berasal lalu kemudian kembali, tidak salah jalan. Innalillahi wa inna ilaihi roji'un!”)

Kutipan di atas membuktikan bahwa kemalangan yang dibawa oleh Romlah sebagai hantu perempuan terselesaikan dengan jalan doa. Hal ini dapat diartikan bahwa dalam masyarakat patriarkhal, perempuan yang tidak memenuhi pengharapan sebagai sosok yang pantas atau ideal mendapatkan "penawar" berupa institusi-institusi, salah satunya adalah institusi agama (contoh institusi lainnya adalah negara, sekolah, keluarga dan pernikahan). Dengan demikian, institusi-institusi patriarkhal (yang dijalankan oleh laki-laki) tersebut masih menjadi jalan keluar bagi laki-laki untuk menjatuhkan kuasa atas tubuh perempuan.

Sedikit berbeda dengan "Mantenan Lan Maesan" cerita-cerita selanjutnya memberikan solusi terhadap hantu perempuan dengan memunculkan orang "pintar" yakni sesepuh desa atau dukun yang memiliki kemampuan untuk mengatasi persoalan hantu perempuan tersebut. Berikut ini adalah kutipan-kutipan dari cerita "Kubur Nyai Jingkrak" tulisan FX Subroto, 
"Kijing Miring" tulisan Winongwong Sih dan "Wanita Ayu Ing Njero Sumur" tulisan FX Subroto.

"Mbok menawa wae, arwahe durung antuk papan kang semesthine, satemah kadhang isih seneng nggodha wong lanang kang lagi kasepen, ngono critane Mbah Saidi" (Subroto, 2013: 39).

("Mungkin saja, arwahnya belum berada di tempat yang seharusnya, sehingga terkadang masih suka menggoda laki-laki kesepian, demikian Mbah Saidi berkata.")

Mbah Saidi sebagai sesepuh desa mengatakan pada Karsono tentang Nyai Jingkrak yang terjebak di antara dua alam. Hal tersebut dikarenakan arwah Nyai Jingkrak belum menemukan tempat yang pantas. Tanpa dia ketahui sebelumnya apakah Karsono adalah lakilaki yang kesepian atau tidak, Mbah Kalil menyimpulkan bahwa Karsono sebagai laki-laki kesepian setelah menyaksikan peristiwa yang menimpanya. Mbah Saidi selain sebagai sesepuh desa, dalam masyarakat Jawa dia juga menyandang julukan sebagai orang "pintar" yaitu orang yang mengetahui hal yang orang biasa tidak ketahui.

"Ora tegel piye! Kowe pinter nyandiwara. Baliya! Kok kira aku ora ngerti sapa kowe, ha! Balia marang wujudmu sakawit. Minggata mumpung durung tak ... “ ... Hiii ... hihihi!" (Sih, 2013: 6).

("Bagaimana aku tidak tega! Kau pintar bersandiwara. Pergi! Kau pikir aku tidak tau siapa kau, ha! Kembali ke wujud asalmu. Pergi sebelum aku ... “ ... "Hiii ... hihi”)

Mbah Kalil adalah satu-satu orang yang tidak tertipu ataupun tergoda oleh hantu perempuan tersebut. Sudah banyak sekali laki-laki yang telah menjadi korbannya bahkan sampai meninggal. Mbah Kalil pula yang menjadi satu-satunya orang yang diceritakan mampu mengusir hantu perempuan yang meresahkan warga tersebut. Tanpa mengenal takut, dia memerintahkan hantu perempuan tersebut untuk segera pergi dengan ancaman yang bahkan sebelum dia ucapkan telah seketika mampu membuat hantu perempuan itu pergi. Dengan demikian dapat diketahui bahwa kemunculan Mbah Kalil dalam cerita ini sebagai penawar dari hantu perempuan tersebut. Mbah Kalil adalah seorang juru kunci kuburan Sendhen, tempat perempuan asing yang mati gantung diri. (Sesaat setelah dikuburkan gundukan tanah kuburannya berguncang dan tanah kubur di bagian kepala amblas sehingga membuat bagian kaki menjadi lebih tinggi. Berdasarkan kejadian tersebut, kemudian masyarakat menyebutnya Kijing Miring.) Mbah Kalil adalah orang yang dituakan, yang telah banyak pengalaman dan mengetahui banyak hal yang kalangan muda tidak ketahui. Perlu diingat bahwa kebanyakan korban dari hantu perempuan Kijing Miring adalah laki-laki muda.

“'Wis, nek ngono pegaweyan iki dilereni sik. Mengko bengi aku tak sowan Mbah Jiwo. Nyuwun srana lan donga. Mbah Jiwo mono sawijining wong pinter ing kampungku. Piyambake pana babagan sing kaya mengkene iki', pratelane Pak Tasim karo ringkes pirantine." ... "Sawise sowan Mbah Jiwo lan diparingi srana lan donga, pegaweyan 
ndandani kompa banyu sing ngadat dhuweke Bu Marsih diwiwiti maneh ing dina candhake" (Subroto, 2013: 51).

("Sudahlah, jika demikian pekerjaan ini ditunda dulu. Nanti malam aku akan sowan ke rumah Mbah Jiwo. Meminta petuah dan doa. Mbah Jiwo itu salah satu orang pintar yang ada di kampungku. Beliau ahli dalam persoalan seperti ini.' Penjelasan Pak Tasim sembari membereskan peralatannya." ... "Setelah sowan ke rumah Mbah Jiwo dan mendapatkan petuah dan doa, pekerjaan memperbaiki pompa air yang macet milik Bu Marsih dimulai lagi esok hari.")

Kutipan di atas menunjukkan bahwa Mbah Jiwo menjadi jalan keluar bagi persoalan yang sedang dialami oleh Pak Tasim dan Tarko. Petuah dan doa yang dia berikan kepada mereka menjadi penawar peristiwa malang yang mereka alami di dalam sumur Bu Marsih. Pak Tasim dan Tarko merasa tenang setelah mengunjungi Mbah Jiwo sehingga pekerjaan memperbaiki pompa air yang rusak dapat mereka lanjutkan esok hari dengan pengharapan arwah penghuni sumur akan berkenan kepada mereka berdua untuk masuk ke dalam sumur. Pak Tasim dan Tarko telah mengetahui kesalahan mereka yang memasuki sumur tanpa permisi namun doa dan petuah dari orang "pintar" tetap menjadi hal yang menenteramkan.

\section{Simpulan}

Pengelompokan kajian seperti di atas mengungkapkan bahwa masyarakat patriarkhal melabeli perempuan dengan mistifikasi-mistifikasi tertentu, salah satunya bahwa perempuan adalah bahaya. Bagi mereka, perempuan dengan kecantikan dan feminitasnya merupakan perangkap bagi laki-laki. Di balik feminitasnya, perempuan dinilai sebagai pihak yang liar, ganas, mengerikan dan membawa kemalangan kepada laki-laki.

Semua perempuan baik yang lugu dan pasif atau perempuan sensual bahkan perempuan asing yang tidak diketahui sejarah hidupnya sekalipun termasuk dalam kategori bahaya bagi laki-laki. Kemalangan yang datang bersama perempuan dapat menimpa semua laki-laki, baik laki-laki baik maupun yang tidak baik. Perempuan berlabel bahaya mengakibatkan dampak negatif bagi laki-laki, dari yang ringan hingga yang paling fatal. Ketakutan, malu dan kesialan adalah akibat paling ringan yang ditimbulkan oleh hantu perempuan. Sedangkan dampak lebih lanjut adalah sakit secara fisik dan sakit dalam bentuk lain. Yang dimaksud dengan sakit dalam bentuk lain adalah ketika laki-laki kehilangan kesadaran dan tidak memiliki kuasa atas dirinya sendiri (orang Jawa sering menyebutnya sawan) dan laki-laki korban dari hantu perempuan juga mengalami kehilangan kewarasan alias gila. Akibat paling fatal dari hantu perempuan yang dialami laki-laki adalah kematian. Dengan demikian dapat disimpulkan bahwa semua perempuan termasuk dalam kategori membahayakan bagi laki-laki bahkan hingga menyebabkan mereka kehilangan nyawa. 
Terdapat solusi yang menyelesaikan cerita tentang keganasan hantu perempuan yaitu kemunculan orang "pintar" atau ahli agama atau aktivitas keagamaan lainnya serta pertaubatan yang dilakukan oleh laki-laki korban hantu perempuan. Dalam hal ini dapat disimpulkan bahwa jalan keluar yang diambil oleh laki-laki untuk lepas dari persoalan perempuan adalah dengan menghadirkan orang "pintar." Orang "pintar" dalam hal ini adalah pihak yang mengerti isu tentang perempuan dan dapat memberikan solusi. Kebanyakan cerita yang dianalisis menunjukkan bahwa para korban memanfaatkan orang "pintar" dan aktivitas keagamaan sebagai solusi mengungkapkan bahwa masyarakat mempercayai bahwa sesepuh desa atau kiai dan pemuka agama adalah pihak yang dirasa memiliki peran dan kapabilitas menyelesaikan masalah tentang perempuan. Dengan demikian, dapat ditarik simpulan bahwa agen-agen patriarkhal seperti sesepuh desa dan kiai adalah kontra bagi perempuan yang tidak memenuhi pengharapan masyarakat patriarkhal tentang sosok perempuan yang baik.

Wanita dalam budaya Jawa diidealkan memiliki feminitas yang tinggi, menjaga kehormatan, tidak melajang dan memiliki anak. Perempuan yang tidak memenuhi kriteria tersebut merupakan wanita yang kurang sempurna di mata masyarakat patriarkhal. Bahkan wanita yang telah memiliki anak diceritakan memiliki keistimewaan dan kekuatan tertentu seperti surga di telapak kakinya dan doa yang manjur bagi anak-anaknya (perlu diingat bahwa tidak semua perempuan dapat memiliki anak, baik dengan alasan kesehatan atau pilihan hidup). Harapan-harapan masyarakat inilah yang memenjarakan perempuan sebagai manusia karena hanya dari feminitasnyalah, perempuan memiliki peran dalam patriarkhi. Kaitannya dengan studi ini adalah ketika perempuan telah meninggal, dia diceritakan juga memiliki kekuatan. Kekuatan yang dimiliki oleh hantu perempuan digunakan untuk mencelakakan laki-laki. Dengan demikian, perempuan baik yang masih hidup atau sudah meninggal, patriarkhi tetap berkuasa atas perempuan.

\section{Daftar Pustaka}

Allen, Virginia. 1983. The Femme Fatale: Erotic Icon. New York: Whitston Publishing Company.

Asshley, Bob (ed). 1997. Reading Popular Narrative. London: Leichester University Press.

Bade, Patrick. 1979. Images of Evil and Fascination Women. New York: Mayflower Books.

Beatty, Andrew. 2003. Varieties of Javanese Religion. Cambridge: Cambridge University Press.

Cawelty, John G. 1976. Adventure, Mystery, and Romance. Chicago: The University of Chicago Press.

Damono, Sapardi Djoko. 1993. Novel Jawa Tahun 1950-an: Telaah Fungsi dan Struktur. Jakarta: Departemen Pendidikan dan Kebudayaan. 
Djokosuyatno, Apsanti. 2005. Cerita Fantastik dalam Perspektif Genetik dan Struktural. Jakarta: Djambatan.

Edwards, Karen L. 2012. The Mother of All Femme Fatales: Eve As Temptress in Genesis 3. London: Palgrave Macmillan.

Geertz, Clifford. 1976. Religion of Java. Chicago: The University of Chicago Press.

Greekmythology.com (diakses pada 15 April 2014).

Handayani, Christina dan Ardhian Novianto. 2004. Kuasa Wanita Jawa. Yogyakarta: LKTiS.

Hutomo, Suripan Sadi. 1976. Telaah Kesusastraan Jawa Modern. Surabaya: Departemen Pendidikan dan Kebudayaan.

Mulder, Niels. 1983. Pribadidan Masyarakat di Jawa. Yogyakarta: Sinar Harapan. . 2006. Doing Java. Yogyakarta: Kanisius.

Praz, Mario. 1933. La Belle Dame Sans Merci. The Romantic Agony. London: Oxford University Press.

Purwadi. 2005. Ensiklopedi Kebudayaan Jawa. Yogyakarta: Bina Media.

Ras, J. J. 1985. Bunga Rampai Sastra Jawa Mutakhir. Jakarta: Grafitipres.

Saadawi, Nawal El. 1985. Two Women In One. London: Saqi Book. . 1990. Memoar Seorang Dokter Perempuan. Jakarta: Yayasan Obor Indonesia. . 2010. Perempuan di Titik Nol. Jakarta: Yayasan Obor Indonesia.

Siddique, Sophie. 2002. "Haunting Visions of Sundelbolong, Vampire Ghost and The Indonesian National Immagery," Spectators (August-October). England.

Soelardi. 1920. Serat Rijanta. Weltevreden: Papyrus.

Sudibyoprono. 1991. Biografi Wayang Purwa. Jakarta: Balai Pustaka.

Suryakusuma, Julia. 2011. Ibuisme Negara. Jakarta: Komunitas Bambu.

Triwikromo, Y Argo. 2006. Mitologi Kanjeng Ratu Kidul. Yogyakarta: Nidia Pustaka.

Utomo, Sutrisno Sastro. 2009. Kamus Lengkap Jawa-Indonesia. Yogyakarta: Kanisius.

Winarsih, Arifin dan Farida Sumargo. 2009. Kamus Prancis-Indonesia. Jakarta: Gramedia. 